JURNAL SENI MUSIK

\title{
TEACHER'S CREATIVITY IN ARRANGING ENSEMBLE MUSIC IN JUNIOR HIGH SCHOOL (SMP) IN PURBALINGGA REGENCY
}

\author{
Antonius Edi Nugroho ${ }^{凶}$ \\ Fakultas Bahasa dan Seni, Universitas Negeri Semarang, Indonesia
}

\section{Article Info}

Submitted : April, 2021

Revised : May, 2021

Accepted : May, 2021

\section{Keywords:}

teacher's creativity, music

arrangement, ensemble

music

\section{Abstract}

Teachers play an important and strategic role as the center of learning resources for the students. A teacher needs to develop the form of musical creativity as much as possible so that it will help the learning process go well, and result in students succeed in achieving their learning objectives. Therefore, this study focuses on the teacher's creativity on (1) the making concept of the ensemble music arrangement in junior high school in Purbalingga Regency, (2) the creation process of the ensemble music arrangement of a medium in junior high school in Purbalingga Regency. The research method used in this study is qualitative with descriptive exposure. The research subjects were music teachers in Purbalingga Regency. Data collection is carried out with observation, interview, and documentation. Data analysis techniques are divided into three stages, namely data reduction, data presentation, and concluding. The results of interviews and observations that have been collected are included in the documentation, images, photographs, field notes, personal records, and other documents after being studied, then reduced into an abstraction. 


\section{INTRODUCTIONS}

Education is very important for everyone. Without education, the quality of a country and national development will not advance. The National Education System is expected to manifest the development of quality for personal welfare and the country. The implementation of education as mandated in Law Number 20 of 2003 on the National Education System is expected to be able to realize the process of developing the quality of students as the next generation of the nation, being a factor for the growth and development of the Indonesian nation and state. Now, education is needed to create quality, intelligent and responsive human beings to be able to innovate continuously so as not to be left behind by other countries. If so, the role of the teacher is very important to provide exemplary results to develop the potential and creativity of students. In addition to the role of the teacher, the determining factor also exists in curriculum improvement (Utomo \& Azimah, 2018).

Art education is a cultural product that contains various kinds of art fields, including music. Music education provides knowledge, understanding, and competence of students about the beauty /aesthetic (reflected through the elements of expression, appreciation, and harmony). So with music, they can develop musical expressions, a mental expression, and appreciation attitude as well as can provide experience in forming harmony with others and nature (Desyandri, 2014).

Learning music in junior high school is an interaction of students and teachers that aims to start creativity, expression, innovating, and appreciating the artwork of music. Implementation of music learning method generally uses lecture and drill, in which the methods are still needed to be developed because music learning in schools not only mastered music and vocal skills, but also to develop critical, appreciative, creative, imaginative, and innovative abilities. So that, students can explore their imagination through the works they made (Utomo, 2018). Learning activity is said to be successful if students are actively involved in the learning process. Utomo (2018) added that student's motivation is also required so the learning process can run optimally. Teachers need to encourage students' motivation in the learning activity. Motivation is an initial capital of students to provide a positive signal to the learning process that is being carried out (Harjono \& Rachman,
2018). In other words, the most important aspect of learning music in junior high school is that students understand the basic theory of music (music theory). It's not a lesson on how to play musical instruments individually and be commercialized but it provides basic subject matter to play music using the school ensemble music instrument.

Music practice lessons at school, namely ensemble music, consisting of piano, recorder, and guitar. Music learning for junior high school is not only ensemble music. Basic theory (music theory) and the practice of vocal music are also taught in the curriculum. In this case, the role of the teacher is very important for the development of students. Learning material includes material under the fields of art and art activity as well as art ideas, artwork skills, and appreciating the sociocultural context of the art (Kusumawati, 2015). Therefore, the purpose of music learning is as basic knowledge of the practice of playing school music instruments and not creating artists who are experts in practicing playing music. Music lessons in school gave understanding in learning basic music starting from hearing, imitating the tone, and playing a musical instrument ensemble school or singing with vowels ranging from tones in the form of songs or rhythms (solfegio). Art learning involves all forms of physical activities and the aesthetic expression activities, explored, appreciated, and created through such a language, sound, motion, and role (visual, music, dance, and theater).

Teacher's creativity greatly provides solutions to students in more appreciating and innovating in participating in learning activities. The role of teachers in the classes determines the learning quality and the spearhead of the success of students in understanding the material delivered. The teacher as the main component of learning has a strategic role, as the main learning resource for the students. Teacher creativity includes the curriculum, methods, media, and teaching materials. To support learning activities, the field of music is chosen (Sitopu, 2015).

Teacher's creativity is supported by innovation in teaching planning. Teachers are expected to be able to design and provide music materials in the form of songs that have been arranged for ensemble music practice at school. The musical ensemble arrangements made by the teacher are expected to attract students to actively participate in learning activities. The teacher's creativity in making song arrangements can be in the form of the main melody of the song that is often heard (cantus firmus), then rewriting the song notation 
by giving other changes to the melody of the song, so that the song arrangement will sound more varied and more pleasant to listen to. More importantly, it is not allowed to change the main melody in the arrangement of the song. This has become the agreement of music arranger activists.

Purbalingga is one of the areas in Central Java. Junior high school music education in Purbalingga is still experiencing slower development than nearby areas such as Purwokerto, Banyumas and Kebumen. Some evidence of the slow development of music education in Purbalingga is based on the lack of musical achievement for junior high school students and the lack of musical ensemble performances at the school and city level.

For some junior high school music teachers in Purbalingga, ensemble music is a subject matter that teaches an introduction to basic music theory and basic music practice that is easy for students at the junior high school level to learn. Musical instruments should also be easy to get because the price is relatively cheap. Novia Eko Utomo, a music teacher at SMP N 5 Mrebet Purbalingga, said that in one-semester meetings, students were taught ensemble material. Before delivering the learning materials, Novia had prepared ensemble music materials and arranged simple songs. Unfortunately, ensemble music arrangements were written manually due to the limited resources and facilities and application software that had not been mastered. In this case, Novia encountered difficulties and obstacles in arranging songs. Based on this, research on teacher creativity in making ensemble musical arrangements is interesting to study. Therefore, this article focuses on the creativity of teachers in arranging ensemble music schools.

\section{METHODS}

In general, the research method used in this study is qualitative with descriptive and interpretive exposure by utilizing qualitative data. That is, in qualitative research a researcher must be able to explain everything that can be trusted with the information he knows and does not cause contradictions with the interpretations presented. The limitation of the problem in this study is based on data that is qualitative in nature and henceforth a conclusion is drawn (Miles. M, B., \& Huberman, 1994).

Data collection techniques used in this study were observation, interviews, and documentation. The main data sources of this study were collected through observation and interviews. Interviews were conducted with several selected informants with a specific purpose, all of the informants were music teachers at junior high schools in Purbalingga. The informants are Novia Eko Utomo, Siwi Rudiatieningsih, Siska Dwi Kartini, Nina Sri Wahyuni. The interview instruments used included the creativity of the teacher in making arrangements, the learning obstacles faced by the music art teacher and the learning methods carried out by the music art teacher. In addition, researchers also collect other data in the form of documents. Documents or anything related to this research such as lesson plans and syllabus.

\section{RESULTS AND DISCUSSION}

A creative person is someone who is always creative. The definition of creating itself is to make something that doesn't exist yet into existence. The basic principle of creativity is similar to innovation, adding value to objects, ways of working, ways of living and so on so that new products that are better than existing products emerge. Art creation implies realizing an art that has new meaning and value (Bahari, 2008). Creativity is a person's ability to produce new and effective work. In addition, creativity is an important thing both in terms of individual and social aspects and can be raised by studying previously existing copyrighted works, which are then updated to produce new art (Sternberg, 1999: 3).

Creativity in music learning is needed to get optimal knowledge, understanding, and mastery of music because the music itself has many creative dimensions. For example, in music, there is an analogy through perceptions, visuals, auditories, anticipation, inductive-deductive thinking, memory, concentration, and logic. In music, it can also be distinguished and learned quickly, high-low, hard-soft that is useful for training sensitivity to environmental stimuli. In addition, music also influences a tool to improve and help develop personal and social capabilities (Djohan, 2005: 141).

In July 2020, researchers conducted preliminary observations at SMP N 05 Mrebet. The researcher had the opportunity to interview Novia Eko Utomo, the school's music teacher. Novia said that she only used a simple arrangement of the Papuan folk song entitled Apuse due to limited resources and facilities and software from the application that had not been mastered so that the arrangement was only done manually, which was only written on paper. 
Because of the obstacles and difficulties faced, Novia emphasizes students in the introduction of students in ensemble music, introduction to various types of musical instruments that can be used in ensemble music, playing a simple arrangement that has been made by music art teachers, instill a sense of responsibility, discipline and collaboration in play a simple song arrangement on ensemble music.

The Researcher felt the need to carry out further investigation on junior high schools in Purbalingga. In August, researchers returned to observe in SMP $\mathrm{N}$ 02 Kutasari, SMPN 3 Kutasari, and SMPN 04 Kutasari. The researcher met Siwi Rudatiningsih, Siska Dwi Kartini, and Nina Sri Wahyuni, teachers in their respective schools to conduct interviews. The data gathered were more or less the same as the previous obtained from Novia Eko Utomo. The teachers experienced obstacles and difficulties to arrange ensemble music. The main obstacle faced is the lack of competence of these teachers. Some teachers taught subjects beyond their fields. For example, dance teachers are required to teach music and vice versa. This is very influential on the creativity of the teacher in making a simple song arrangement. Another obstacle is the lack of mastery of software applications for arrangements, so the arrangement is done simply manually written on paper.

In addition, due to the outbreak of the Covid-19 pandemic, the researcher went to Purbalingga in October 2020 to conduct related research. The Researcher conducted interviews with 4 teachers that the researchers had met at the initial observation, Novia Eko Utomo, Siwi Rudiatingeningsih, Siska Dwi Kartini, and Nina Sri Wahyuni, at SMP N 05 Mrebet Purbalingga. On observation, the researchers saw the process of teachers directly in making arrangements of simple songs, and the creativity of the teacher in making arrangements and arrangement forms.

Unfortunately, researchers cannot observe the teaching and learning process in the class directly in the musical subjects Ensemble with simple songs that have been arranged because learning is carried out online during the Covid - 19 pandemic.

On observations that the researcher did in October of 4 teachers, the researcher asked the teachers to arrange the Papuan Folk song, Apuse, with the theme or learning material align with core competencies (KI) and basic competencies (KD) contained in the 2013 curriculum. Here is an example of the results of the Apuse song arrangement made by one of the teachers.

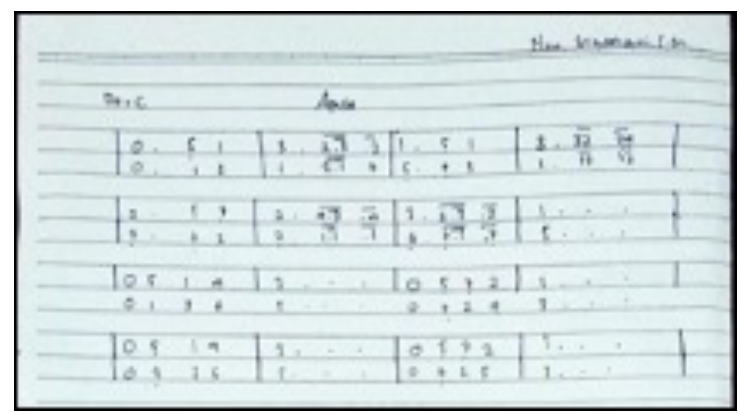

Figure 1: The example of arranging Voice 2 on a piano.

The arrangement of the song on the melodica piano instrument (Figure 1) was made by Sri Wahyuni, who was one of the junior high school teachers. The song is the Apuse song, using the basic tone $\mathrm{C}=$ Do. In the picture, Sri Wahyuni compiled a voice 2 according to the laying of the notation and the value of the tone on the original song. Notation on Voice 2 is adjusted to the tonic in the stable song notation without additional arrangements.

Apuse's song arrangement from other teachers was not much different from Sri Wahyuni. Its form is the piano play without changes in the tone that matches the original notation.

\section{CONCLUSION}

Creativity is a means to express expression, imagination, and appreciation in music. One of the cultural arts/music learning activities is to express oneself through making school ensemble music arrangements. The creativity of teachers at a public junior high school in Purbalingga Regency can be seen in the creation of two voices on the piano instrument. The result is a tonic playing without changing the pitch value according to the original notation.

Constraints and difficulties faced by teachers in making musical ensemble arrangements vary, from the lack of mastery of application software for arrangements, the competencies possessed by teachers are not following their fields to limited sources of material. Various constraints and difficulties exist, causing the teacher's creativity in making musical ensemble arrangements is not optimal.

\section{REFERENCES}


Bahari, Nooryan. 2008. Kritik Seni. Yogyakarta : Pustaka Pelajar

Desyandri, D. (2014) . Peran Seni Musik dalam Pendidikan Multikultural. Jurnal Pembangunan Pendidikan Fondasi Dan Aplikasi.

Djohan. 2005. Psikologi Musik. Yogyakarta: Buku Baik.

Harjono, R., \& Rachman, A. (2018).

Kreativitas Guru Dalam Pembelajaran Ekstrakurikuler. Jurnal Seni Musik.

Kusumawati, H. (2015). Kreativitas Dalam Pembuatan Aransemen Musik Sekolah. Jurusan Pendidikan Seni Musik, FBS, Universitas Negeri Yogyakarta.
Miles. M, B., \& Huberman, A. M. (1994). Qualitative Data Analysis (2nd ed.) (2nd ed.). Sage Publications.

Sitopu Riyanto. 2015. Kreativitas Guru dalam Pembelajaran Seni Musik TK Pertiwi 34 Patemon Kecamatan Gunungpati Kota Semarang.

Sternberg, J. Robert. 1999. Handbook of Creativity. New York: Cambridge University Press.

Utomo, U., \& Azimah, N. (2018). Kreativitas Guru Dalam Menggunakan Lagu-Lagu Pada Pembelajaran Tematik Di Sekolah Dasar. Jurnal Seni Musik. 